ARTICLE

DOI: $10.1038 / s 41467-017-00966-x$

\title{
Coralgal reef morphology records punctuated sea-level rise during the last deglaciation
}

\author{
Pankaj Khanna (1) ${ }^{1}$, André W. Droxler ${ }^{1}$, Jeffrey A. Nittrouer ${ }^{1}$, John W. Tunnell $\mathrm{Jr}^{2} \&$ Thomas C. Shirley ${ }^{3}$
}

Coralgal reefs preserve the signatures of sea-level fluctuations over Earth's history, in particular since the Last Glacial Maximum 20,000 years ago, and are used in this study to indicate that punctuated sea-level rise events are more common than previously observed during the last deglaciation. Recognizing the nature of past sea-level rises (i.e., gradual or stepwise) during deglaciation is critical for informing models that predict future vertical behavior of global oceans. Here we present high-resolution bathymetric and seismic sonar data sets of 10 morphologically similar drowned reefs that grew during the last deglaciation and spread $120 \mathrm{~km}$ apart along the south Texas shelf edge. Herein, six commonly observed terrace levels are interpreted to be generated by several punctuated sea-level rise events forcing the reefs to shrink and backstep through time. These systematic and common terraces are interpreted to record punctuated sea-level rise events over timescales of decades to centuries during the last deglaciation, previously recognized only during the late Holocene.

\footnotetext{
${ }^{1}$ Department of Earth, Environmental and Planetary Sciences, Rice University, 6100 Main St, Houston, TX 77005, USA. ${ }^{2}$ Harte Research Institute for Gulf of Mexico Studies TAMU-CC, 6300 Ocean Dr., Corpus Christi, TX 78412, USA. ${ }^{3}$ Department of Life Sciences, TAMU-CC, 6300 Ocean Dr., Corpus Christi, TX 78412, USA. Correspondence and requests for materials should be addressed to P.K. (email: pankaj89@gmail.com) or to A.W.D. (email: andre@rice.edu)
} 
C oralalgal reef establishment and evolution during the last deglaciation have been well documented through chronological, sedimentological, and paleontological studies, and provide unique data sets upon which past sea-level records have been reconstructed ${ }^{1-15}$. Most of these records display, since the Last Glacial Maximum (LGM), several major intervals of rapid sea-level rise over timescales of several centuries, referred to as melt water pulses, in the uppermost Pleistocene.

Since the early $1930 \mathrm{~s}^{16}$, several deep banks, with crests lying in about $60 \mathrm{mbsl}$, were known to occur along the south Texas shelf edge (Fig. 1). The coralgal origin of the banks was first proposed in the mid-1970s ${ }^{17,18}$ based on five banks from which rock samples were collected by piston coring, dredging, box coring, and Van Veen grab. The rocks consist mainly of dead corals (Agaricia sp., Madracis sp., Madracis asperula, Madracis brueggemanni, Madracis myriaster, and Paracyathus pulchellus) and coralline algal nodules. Only two samples were dated; a coral sample from the top of Dream Bank at $68 \mathrm{~m}$ yielded a radiocarbon age of $10,580 \pm 155$ years BP $(11,901.5 \pm 335.5$ calendar years BP), and a coralline algal sample from the base of Southern Bank produced a radiocarbon age of $18,900 \pm 370$ years BP $(22,361 \pm 428 \text { calendar years BP })^{17,18}$. In late 1990 s, a multichannel seismic grid on one of the reefs, Southern Bank, indicates the thickness of the bank to be about $40-50 \mathrm{~m}^{19}$. It is also concluded that the drowned banks along the south Texas shelf edge were established on paleo highs associated with antecedent siliciclastic topographies such as either beach barrier islands or beach ridges developed during late LGM or earliest deglaciation $^{19}$. In absence of detailed chronologic dates and based upon the current water depth range of these bank tops at about $60 \mathrm{mbsl}$, the demise of these reefs was proposed to have occurred between $\sim 12,250-11,500 \mathrm{Cal} \mathrm{BP}$. Recent studies show that during the LGM, the south Texas coastal system consisted of a bay bounded by the Rio Grande and Colorado lowstand shelf edge deltas, isolated from the open ocean by a barrier island complex ${ }^{20}$ (Fig. 1b). The coralgal reefs likely established themselves on top of this lowstand coastal system, thrived, and grew vertically in less than $\sim 8000$ years by tracking the $40-50 \mathrm{~m}$ of sea-level rise during the uppermost Pleistocene ${ }^{19-21}$. Ultimately, the south Texas reefs drowned and, starting at $\sim 9 \mathrm{ka}$, were subsequently partially buried by the Holocene Texas Mud Blanket ${ }^{17-21}$ (TMB).

The observed $40-50 \mathrm{~m}$ vertical accretion of the coralgal banks in about 8000 years suggests average rates of sea-level rise of $5-6 \mathrm{~m}$ per millennium, as in published sea-level records $1,2,12,13$. This pace could have occurred only with the occurrence of scleractinian coral species, including Acropora palmata and Acropora cervicornis, which display unusually fast growth rates and create the main coral framework of the Caribbean reefs ${ }^{22}$. Although these species are not currently growing at the latitudes of the northern Gulf of Mexico (GoM), except for a few colonies of $A$. palmata newly established at the Flower Garden Banks (FGB) (Fig. 1a) in the past decade $^{23}$, it is assumed that these species formed the coral framework of the south Texas shelf edge drowned banks. This assumption is bolstered by the recent discovery that $A$. palmata and $A$. cervicornis grew in large numbers at the base of the $\mathrm{FGB}^{24}$ as early as $10,200 \mathrm{cal} \mathrm{BP}$, based on radiocarbon dating. The occurrence of these coral species as early as the earliest part of the Holocene in the northern GoM strengthens the inference that they most likely form the coral framework of the uppermost Pleistocene south Texas shelf drowned banks. Additionally, modern and presumably deglacial near-surface circulation patterns in the GoM show that it is and was responsible for carrying biotic communities into the GoM from the Caribbean ${ }^{25}$.

It has been established that carbonate production areas shrink through backstepping so to remain within the euphotic zone when responding to sea-level rise; as such coralgal reefs form distinct sets of terraces ${ }^{26}$ as they grow vertically keeping up with sea-level rise. During transgressions, therefore, episodic and rapid sea-level rise events result in set of terraces, preserving the nature of sea-level rise and diagnostic morphological features of reefs struggling to keep up with rising sea-level ${ }^{26-30}$. Ultimately, when the area of carbonate production has shrunk to a minimum through systematic backstepping, reefs are unable to grow
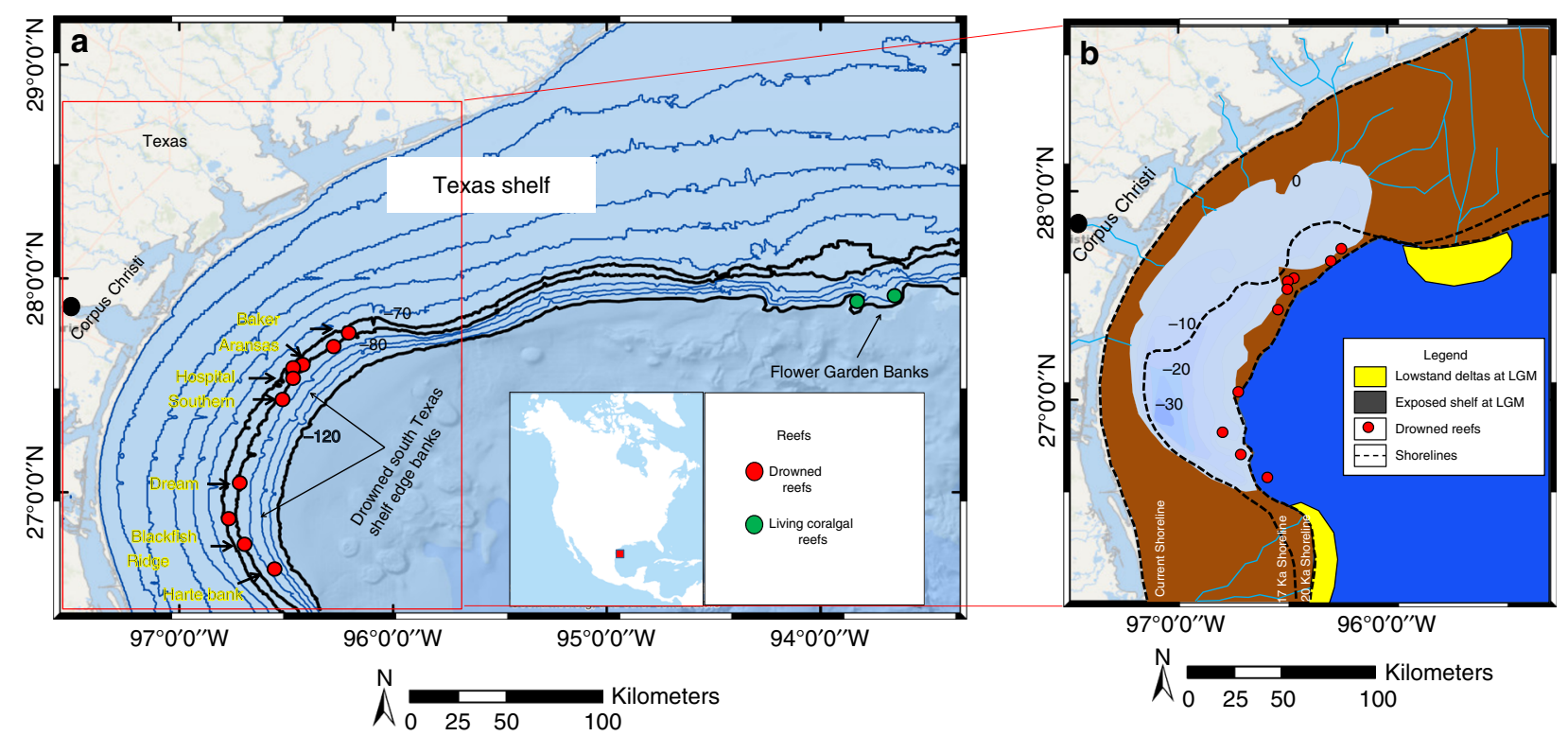

Fig. 1 Modern and uppermost Pleistocene Texas shelf where living and drowned coralgal reefs are located. a Drowned banks along the south Texas shelf edge are shown as red dots. The Flower Garden Banks, living coralgal reefs $150 \mathrm{~km}$ south of Galveston Island, are displayed as green dots. Note that, with one exception, the drowned reefs are currently located between 70 and $80 \mathrm{~m}$ isobaths. b Uppermost Pleistocene south Texas shelf coastal systems at 20 and $17 \mathrm{ka}^{20}$ (located in Fig. 1a by red rectangle), illustrate a shallow bay up to $35 \mathrm{~m}$ deep, isolated from the open ocean by a barrier island complex, on top of which the south Texas reefs (shown in red dots) were established during the early part of last deglaciation 


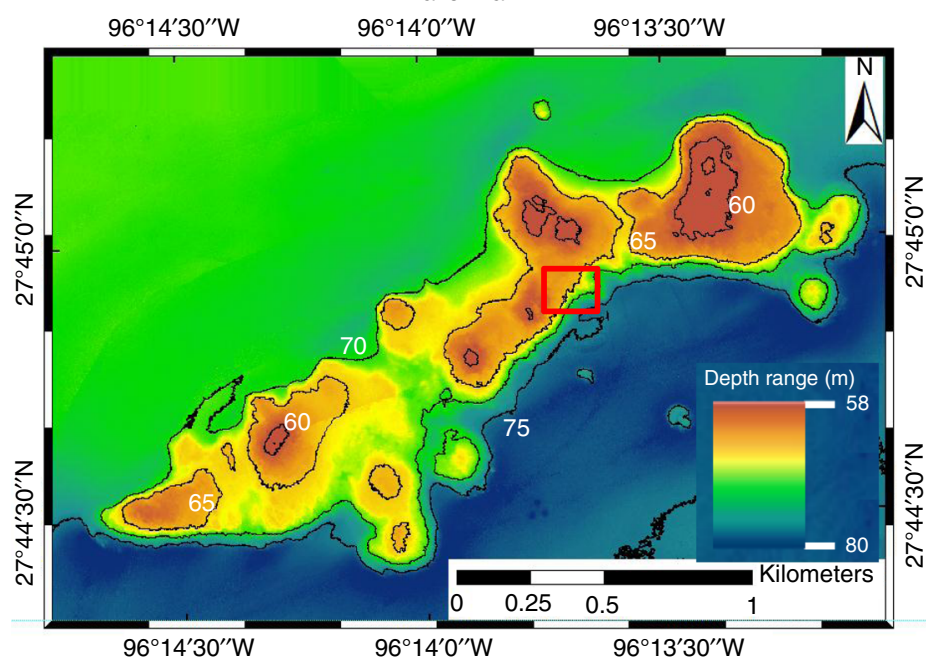

C

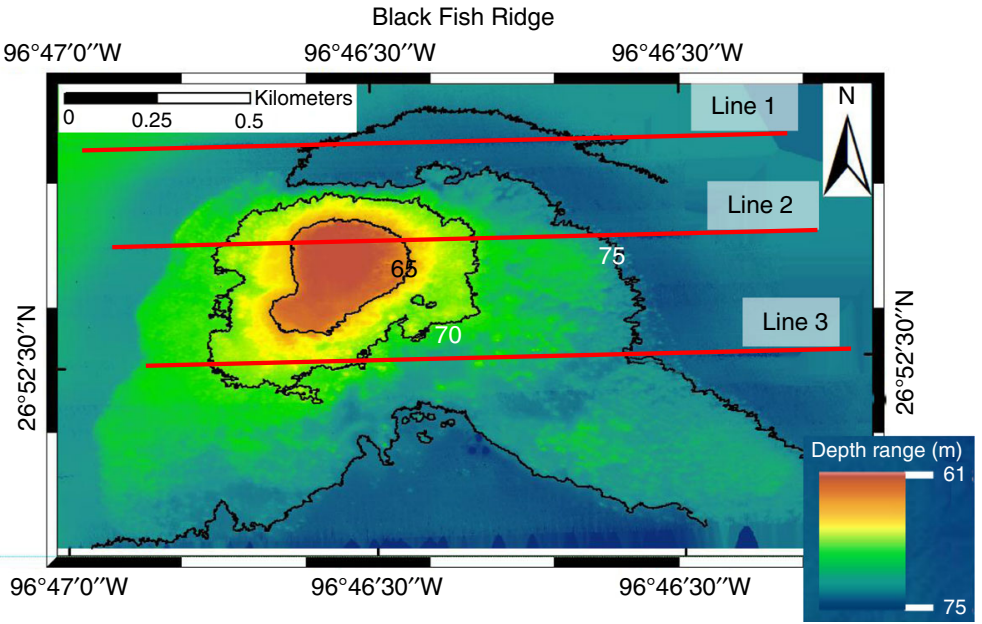

b

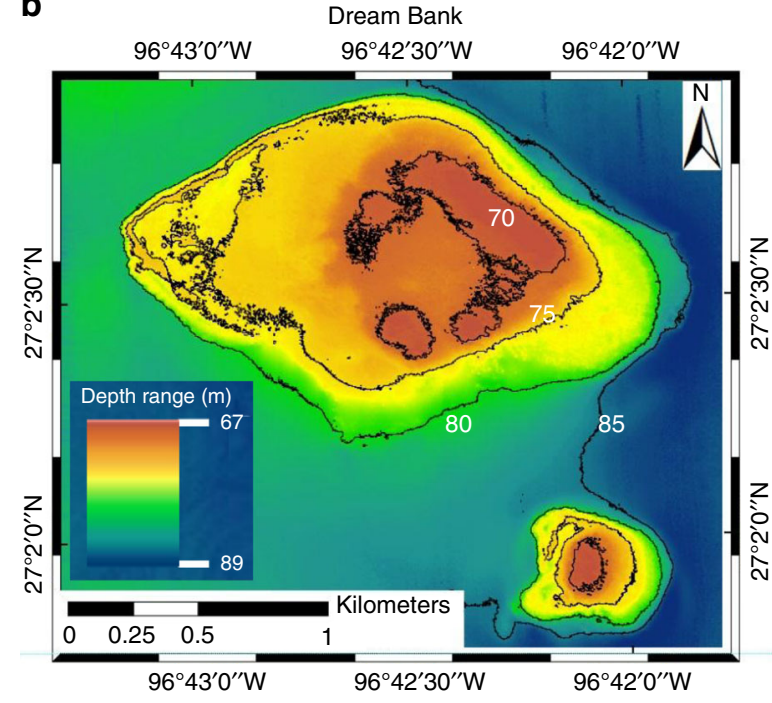

d

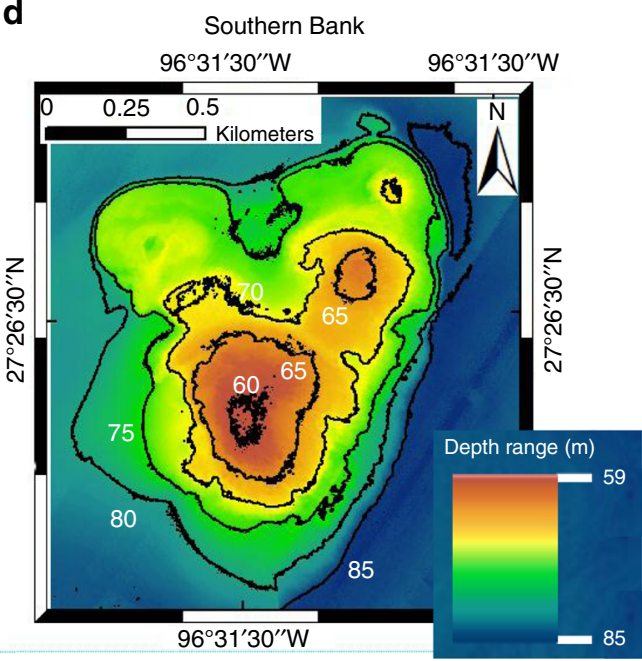

Fig. 2 High-resolution multibeam bathymetric maps illustrate the morphology of four of the ten imaged drowned coralgal reefs. a Baker Bank, b Dream Bank, c Blackfish Ridge, and $\mathbf{d}$ Southern Bank (see Fig. 1a for their geographical locations). Spurs (ridges) and grooves (troughs) are usually identified on the south-eastern (windward) side of the banks; the red rectangle in Fig. 2a locates well-developed spurs and grooves shown in Fig. 3a. Dream Bank in Fig. 2b represents distinct atoll morphologies, with well-developed lagoons surrounded by rimmed margins (see Fig. 3c). Dream Bank also clearly displays a set of distinct terraces, illustrated in Fig. 3d, e. Red lines on Fig. 2c locate the three $3.5 \mathrm{kHz}$ seismic lines $(1,2,3)$ shown in Fig. 4

vertically fast enough to keep up so as to remain within the euphotic zone and reefs ultimately drown ${ }^{26,31}$. The edifices of drowned reefs sit below the euphotic zone, as the series of drown banks along the south Texas shelf edge, which are no more vertically accreting, although their crests are still covered by live ahermatypic wire corals, sea-fans, mollusks, annelids, bryozoans, and red algae, and are known to be excellent fishing grounds ${ }^{32}$.

The new data presented here provides an opportunity to quantify well-imaged back-stepping terraces and identify nature of the sea-level rise during last deglaciation leading to the development of common backstepping morphologies. High-resolution multibeam mapping and seismic profiling of 10 drowned banks, located along a 120-km-long stretch of the south Texas outer shelf, identify six common terrace levels; these identical morphologies provide new opportunities to understand coralgal reef evolution through backstepping and terrace formation, most likely triggered by decade to century-long punctuated sea-level rise during the middle part of last deglaciation. Existing sea-level records do not have the ability to resolve these smaller amplitude variations. Hence, it is pertinent to investigate geological records that directly document spatiotemporal sealevel changes to determine if decadal to century-scale sea-level rise episodes are common occurrences.

\section{Results}

True coralgal reef morphologies. Multibeam bathymetric mapping and $3.5 \mathrm{kHz}$ seismic profiling, acquired in September 2012, onboard the R/V Falkor (Fig. 2 and Supplementary Figs. 1-6), showcase the detailed morphological architecture of the south Texas shelf edge drowned banks. Spurs and grooves, typical morphological adaptations to high-energy inner fore reef conditions $^{33,34}$ (Figs. 2a and $3 \mathrm{a}, \mathrm{b}$ ), are preferentially observed in the high-resolution bathymetry on the south-eastern margins of several mapped banks and, therefore, coincident with their windward high-energy sides; on their protected northwestern lee sides, these features are conspicuously absent. In mid1970, spurs and groves were already observed, aligned perpendicular to the slope of the bank, by submarine operations using DRV Diaphus ${ }^{35}$. Moreover, the new data presented here provides 
a

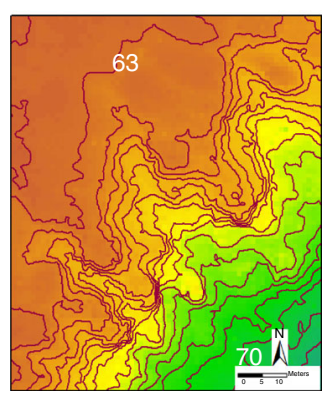

b

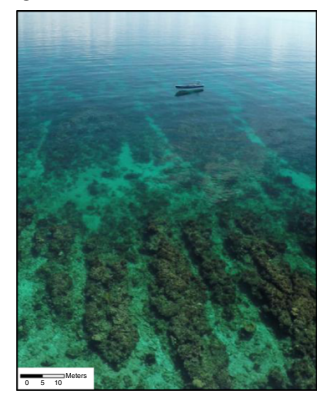

c

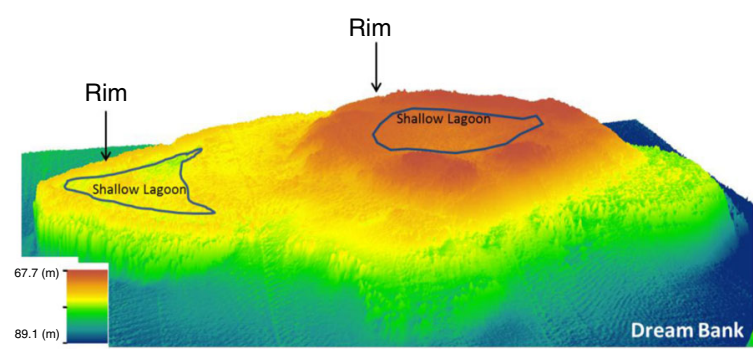

d
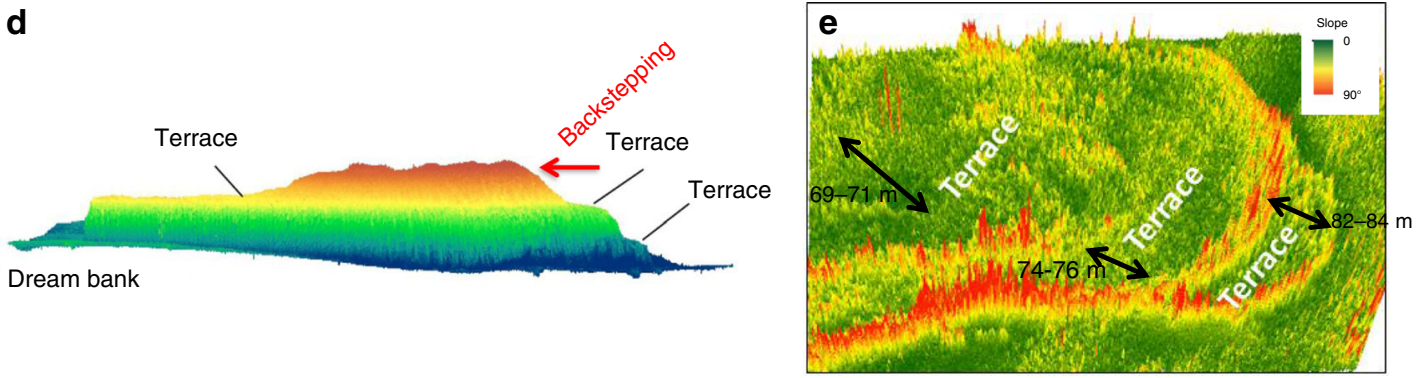

f

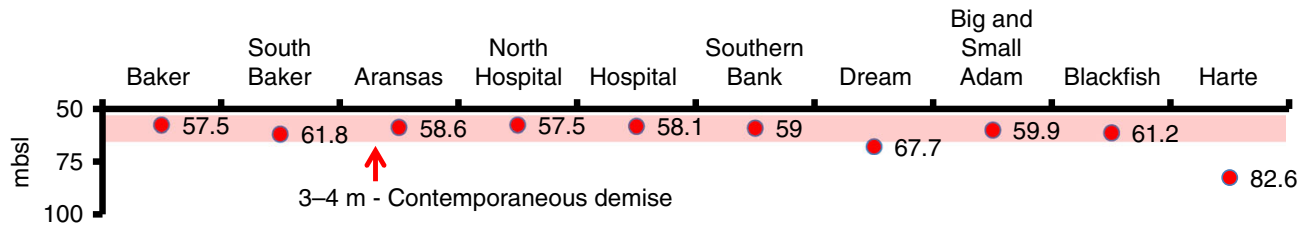

Fig. 3 True coralgal reef morphologies as evidenced by high-resolution multibeam bathymetric maps. a Detailed bathymetry (contour interval $0.5 \mathrm{~m}$ ) displays a clear example of spurs and grooves on the south-eastern margin of Baker Bank (see Fig. 2a for location), b Picture of modern spurs and grooves in front of the Belize Barrier Reef east of Tobacco Range, (Photo by Brandon Martin) as an analog for Fig. 3a; note the similar scales between both fossil and modern spur and grove sets. c Oblique bird eye view of Dream Bank displays clear atoll morphologies, rimmed margins enclosing shallow lagoon, at two different levels. $\mathbf{d}$ Side view of Dream Bank (VE: $\times 20)$ displays a series of terraces, characteristic morphology of coralgal reef backstepping in response to punctuated high rates of sea-level rise ${ }^{26}$. e Slope angle map for Dream Bank clearly identifies the well-defined terraces and faces (shown in 3D), where red color (steep slopes) represents terrace faces and green color (gentle slopes) terrace flats. $\mathbf{f}$ Plotted depths to crest of the ten drowned banks, eight of which lie within a 3-4 m-depth range from 57.5 to $61.8 \mathrm{mbsl}$. Such a narrow depth range testifies to their contemporaneous demise

an opportunity to quantify well-imaged backstepping terraces (Fig. 3c-e), defined as flat areas bounded by steep slopes, common in nine of the ten surveyed banks. These terraces, separated by $1-2 \mathrm{~m}$ high faces of coralgal reef rock as was previously observed using submersibles ${ }^{35}$, are quantitatively analyzed based on multibeam data. Additionally, Dream Bank displays narrowrimmed margins enclosing shallow lagoons at two different backstepping terrace levels, typical coralgal atoll morphologies (Fig. 3c).

Ultimate coralgal reef demise. The $57.5-61.8 \mathrm{mbsl}$ depth range in which the crests of eight of the ten drowned coralgal reefs occur, point to their contemporaneous demise (Fig. 3f). Furthermore, this depth range coincides with stranded paleoshorelines and subtidal shoal complexes observed in the $\mathrm{GoM}^{36}$ $(\sim 58 \mathrm{mbsl})$, Caribbean ${ }^{37}(\sim 57 \mathrm{mbsl})$, and Southwest Pacific ${ }^{37}$ $(\sim 56 \mathrm{mbsl})$. These paleo-shorelines and shoals are interpreted to have been abandoned by an $\sim 11.5 \mathrm{ka}$ event of rapid rise in global sea level, linked to the onset of MWP-1B occurring at the end of the Younger Dryas ${ }^{1,15}$. It is hypothesized, therefore, that the final demise of the south Texas drowned banks was triggered by the MWP-1B, at $\sim 11.5 \mathrm{ka}$. The coralgal reefs could not keep up 26,31 with the rapid rise in sea level because their carbonate production surface areas had shrunk to a minimum through systematic backstepping, as an overall response to the last deglaciation sea-level transgression.

Stressors other than sea-level rise can negatively affect coralgal community growth, such as fluctuations in water turbidity, temperature, and salinity. However, siliciclastic sediment influx into the south Texas shelf edge was minimal during the uppermost Pleistocene transgression ${ }^{20}$, when coastlines migrated landward. Initial burial by the TMB was initiated at $\sim 9 \mathrm{ka}$, and thereby post-date reef drowning by $\sim 2.5 \mathrm{ka}$. Temperature and salinity likely did not trigger the widespread collapse of the south Texas banks. During the Younger Dryas, sea surface temperatures dropped only by $\sim 1.5^{\circ} \mathrm{C}$ to reach $26^{\circ} \mathrm{C}$, and sea surface salinity increased from 34 to 36.5 parts per thousand in the northern $\mathrm{GoM}^{38}$. These nominal changes likely did not modify the coralgal reef ecology because during the time period of reef development, sea surface temperatures and salinity are estimated to have fluctuated with an even greater magnitude, between 25 and $29^{\circ} \mathrm{C}$, and 34-38 parts per thousand, respectively ${ }^{38}$.

Terrace hypsometric analysis. Hypsometric curves, generated from eight banks, identify sets of backstepping terraces at uniform water depths, within a range spanning 75-60 mbsl. Four individual terraces are identified at: $74 \pm 1,70.5 \pm 1.5,66.5 \pm 1.5$, and $63 \pm 1 \mathrm{mbsl}$. The terraces are separated by $2-4$-m-high steep face. As imaged in $3.5 \mathrm{kHz}$ seismic lines, a fifth well-developed 

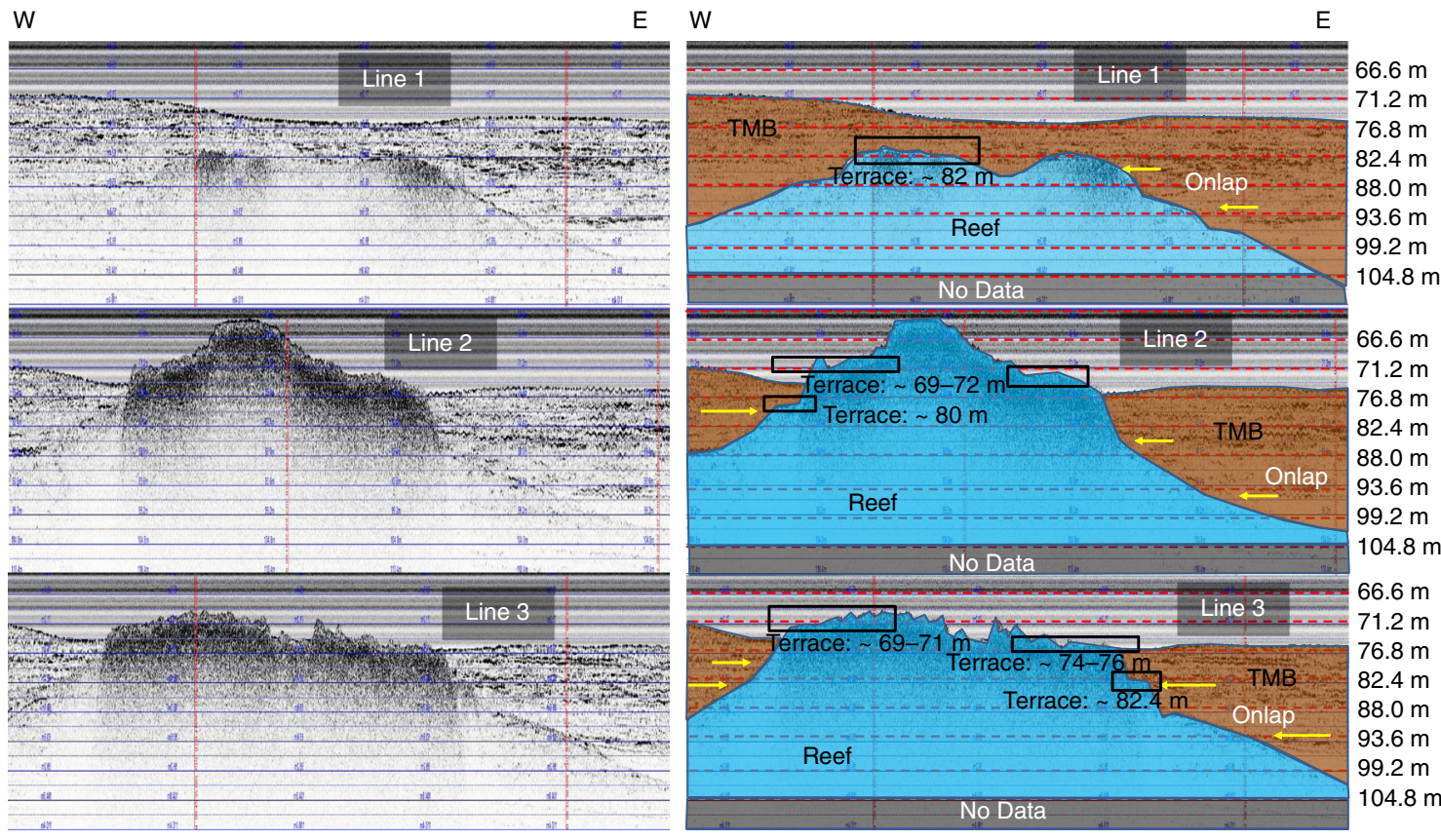

Fig. 4 A $3.5 \mathrm{kHz}$ Chirp uninterpreted and interpreted lines acquired over Blackfish Ridge Bank. The three seismic lines are located in Fig. 2c. Coralgal reef is colored in blue, the TMB, partially burying the reef, in brown; yellow arrows point to clear onlaps on the reef by the TMB. Three terrace levels, the deepest at $82 \mathrm{mbsl}$ and two shallower terraces at $74-75$ and $69-71 \mathrm{mbsl}$, are identified and are marked by black rectangles

common terrace, buried by the TMB, is identified at $82 \pm 1 \mathrm{mbsl}$ (Figs. 4 and $5 \mathrm{a}$ and Supplementary Figs. 1-6). Moreover, a sixth terrace was mapped at $94 \pm 1.5 \mathrm{mbsl}$ only on Harte Bank(the deepest bank with an exposed crest and base at 82 and 102 mbsl, respectively; Supplementary Fig. 7), discovered during the 2012 research expedition aboard the R/V Falkor cruise. Because both subsidence and glacio-isostatic adjustment (GIA) rates are assumed to be identical along this $120 \mathrm{~km}$ of the south Texas shelf, the observed five common terrace depth ranges can be considered coeval. Despite the absence of systematic chronologic dates for each of the terraces, their consistent depth ranges, among several reefs growing over such this long stretch of the south Texas shelf edge, are interpreted to reflect contemporaneous and systematic backstepping linked to punctuated sea-level rises.

Paleo terrace depth estimates. Sea-level changes are dependent on ice-sheet growth and decay, tectonics, and sediment overloading of the shelf and vary in different parts of the world, referred to as relative sea-level (RSL). RSL curves incorporate eustatic sea-level (ESL) fluctuations and it is usually difficult to separate the two (RSL and ESL). The Northwestern GoM is an ideal location for which RSL drivers and their amplitudes are well constrained and provides the opportunity to examine ESL signals. The two main drivers for RSL change in northern GoM are GIA ${ }^{39}$ (0.71 mm per year of uplift since 21,000 calendar years BP), and subsidence $^{40}(0.5 \mathrm{~mm}$ per year from past 21,000 years). Considering a linear rate for GIA and subsidence for the last deglaciation, and the current depth of the terraces on drowned banks, the depth of each terrace is recalculated and used as indicator of ESL (Table 1). The corrected depths are compared with an icevolume sea-level curve ${ }^{15}$ to calculate the corrected age range with uncertainties, during which each of the six terraces was developed. These calculations are based on two assumptions: the GIA and subsidence rates are linear, and the development of terraces occurred at sea level. The uncertainties associated with the age model are dependent upon the GIA, subsidence, and relation of paleo water depth to terrace depth. Calculating GIA and subsidence with corrected age model demonstrates that the deviation in the GIA and subsidence are less than three percent. Further, atoll and spur-groove morphologies, clearly observed in the highresolution bathymetric data sets, indicate that the reefs, when flourishing, were keeping up with sea level.

Paleo terrace depths and Greenland climate record. The corrected depths of the observed six common terrace levels, identified on the south Texas banks, are projected onto a global eustatic sea-level curve ${ }^{15}$ (Fig. 5b) and their equivalent ages with uncertainties are estimated based on these projections. Then, these ages with their associated uncertainties are projected onto the NGRIP $\delta^{18} \mathrm{O}$ record ${ }^{41,42}$. This climate record from Greenland is, to our knowledge, the only existing high-resolution upper Pleistocene climate record during which the six terraces were formed along the south Texas shelf. The comparison of both records is the only possible opportunity to attempt to understand the cause and effect relationship between warm climate intervals, melting of glaciers (ice-stream/ice-sheet collapse), sea-level rise events, and terrace development. As observed in Fig. 5b, out of the six terraces, four terraces correspond to warm interstadials, one to a stadial-interstadial transition, and one only to a cold stadial. The NGRIP $\delta^{18} \mathrm{O}$ record represents climate variations in Greenland. Figure $5 \mathrm{~b}$ further illustrates that the number of occurrence of the terrace depth zones are similar to the number of warm events observed on NGRIP $\delta^{18} \mathrm{O}$ record. Moreover, the correlation of each terrace to a warm interstadial period, with one exception, is noteworthy. These warm periods, therefore, can further be linked to ice-sheet/ice-stream collapse events, causing rapid sea-level rise events of the orders of few meters per century, which lead to the development of common terrace morphologies on south Texas shelf banks.

\section{Discussion}

In absence of correct chronologic dates, the formation of these terraces, common to nine coralgal reefs, located along a distance 
a Percentage of Bank Area

b Age (kyr BP)

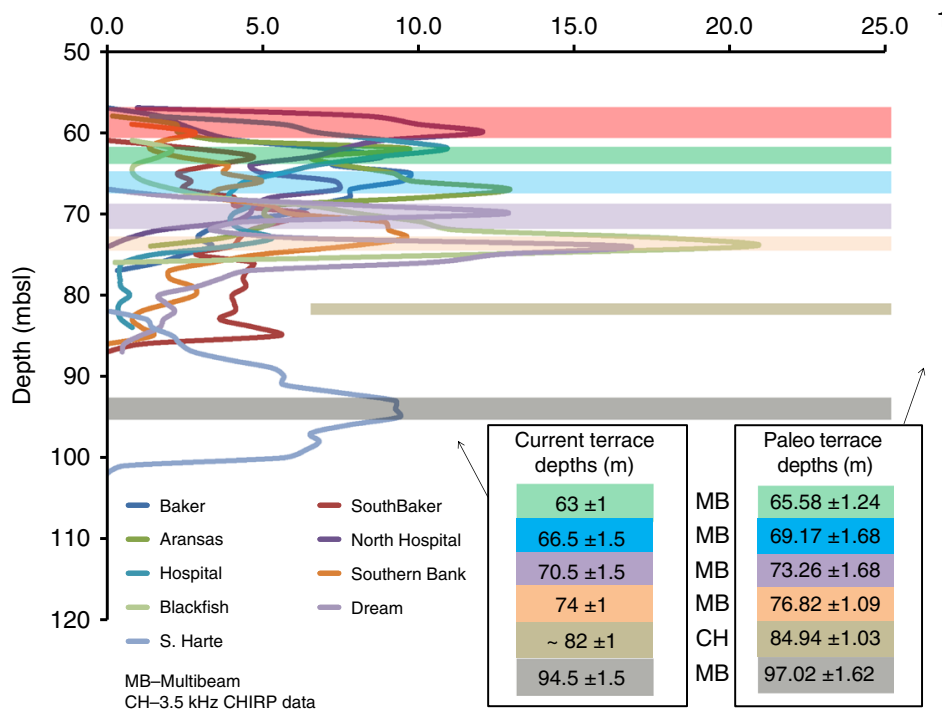

11.011 .512 .012 .513 .013 .514 .014 .515 .015 .516 .0

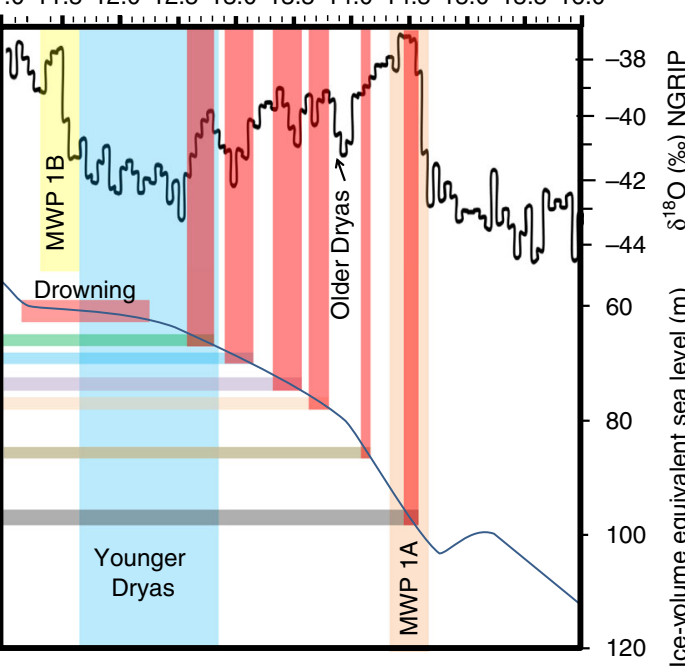

Fig. 5 Punctuated sea-level rise events over timescales of decades to century based on coralgal reef terrace levels and their connection with warming intervals in the North Greenland Ice Core Project climate record during last deglaciation. a Hypsometric curves for nine south Texas shelf drowned banks, based on high-resolution multibeam bathymetry data and $3.5 \mathrm{kHz}$ seismic lines, identify the occurrence of a series of terraces common to the banks. Each depth range (mbsl) of the four common shallower terraces is based on the multibeam data sets, green $(63 \pm 1 \mathrm{~m})$, blue $(66.5 \pm 1.5 \mathrm{~m})$, purple $(70.5 \pm 1.5 \mathrm{~m})$, and orange $(74 \pm 1 \mathrm{~m})$. Two of those terraces (purple and orange), in addition to a deeper one at $82 \pm 1 \mathrm{~m}$, are also identified on the $3.5 \mathrm{kHz}$ seismic lines (Fig. 4). An additional terrace level is identified on the multibeam map of Harte bank (deepest bank): gray ( $94.5 \pm 1.5 \mathrm{~m}$ ). b Paleo terrace depths (Table 1) with uncertainties are projected onto the ice-volume equivalent sea-level curve $\mathrm{e}^{15}$. The age equivalent of each terrace is projected onto the NGRIP $\delta^{18} \mathrm{O}$ record ${ }^{41,42}$ with associated uncertainties (red vertical bands). The Younger Dryas interval is represented by a blue band. Melt water pulses (MWP) $1 \mathrm{~A}$ and $1 \mathrm{~B}$ are represented by vertical light red and yellow bands

Table 1 Estimated Paleo terrace depths and their age range (see details in the text and methodologies)

\begin{tabular}{lllllll}
$\begin{array}{l}\text { Depth of } \\
\text { terrace }\end{array}$ & $\begin{array}{l}\text { Inferred age from } \\
\text { terrace depth } \\
\text { (calendar years BP) }\end{array}$ & GIA $(\mathbf{m})$ & Subsidence $(\mathbf{m})$ & $\begin{array}{l}\text { Total depth } \\
\text { change }(\mathbf{m})\end{array}$ & $\begin{array}{l}\text { Paleo } \\
\text { terrace } \\
\text { depth }(\mathbf{m})\end{array}$ & $\begin{array}{l}\text { Inferred age range from } \\
\text { Paleo terrace depth } \\
\text { (calendar years BP) }\end{array}$ \\
\hline $59.25 \pm 1.75$ & $11,375 \pm 275$ & $8.07 \pm 0.20$ & $-5.68 \pm 0.13$ & $2.38 \pm 0.33$ & $61.63 \pm 2.08$ & $11,200-12,400$ \\
(Drowning) & & & & & \\
$63 \pm 1$ & $12,300 \pm 200$ & $8.73 \pm 0.14$ & $-6.15 \pm 0.1$ & $2.58 \pm 0.24$ & $65.58 \pm 1.24$ & $12,550-12,800$ \\
$66.5 \pm 1.5$ & $12,750 \pm 150$ & $9.05 \pm 0.11$ & $-6.37 \pm 0.07$ & $2.67 \pm 0.18$ & $69.17 \pm 1.68$ & $12,900-13,150$ \\
$70.5 \pm 1.5$ & $13,150 \pm 150$ & $9.33 \pm 0.11$ & $-6.57 \pm 0.07$ & $2.76 \pm 0.18$ & $73.26 \pm 1.68$ & $13,300-13,550$ \\
$74 \pm 1$ & $13,475 \pm 75$ & $9.56 \pm 0.05$ & $-6.73 \pm 0.03$ & $2.82 \pm 0.09$ & $76.82 \pm 1.09$ & $13,650-13,800$ \\
$82 \pm 1$ & $14,025 \pm 25$ & $9.94 \pm 0.02$ & $-7 \pm 0.01$ & $2.94 \pm 0.03$ & $84.94 \pm 1.03$ & $14,050-14,150$ \\
$94 \pm 1.5$ & $14,400 \pm 100$ & $10.22 \pm 0.07$ & $-7.2 \pm 0.05$ & $3.02 \pm 0.12$ & $97.02 \pm 1.62$ & $14,450-14,550$ \\
\hline
\end{tabular}

of over $120 \mathrm{~km}$ on the south Texas shelf edge, indicates that during the recent peak deglaciation sea level did not always rise gradually, but rather was characterized by a series of punctuated and rapid sea-level rise events over decades to one century, previously only recognized during late Holocene $e^{43,44}$. Because climate warming and resulting ice-sheet collapses have been predicted for the future decades and centuries ${ }^{45,46}$, the steady and gradual sea-level rise, observed over the past two centuries may, therefore, not be a complete characterization of how sea level would rise in the future. Furthermore, there is a scientific need to utilize advanced technologies, including high-resolution bathymetry systems combined with systematic drilling of reefs and accurate dating techniques; this study serves as a guide to future research endeavors that seek to inform sea-level rise rate and amplitude projections. Researchers that model sensitivity of sea-level fluctuations-past and present-require as much information as possible regarding smaller amplitude events, and the best place to find this information is from the geological record. The documentation of decades to century-scale punctuated sea-level rise events with magnitudes of a few meters implies that deglaciation and associated sea-level rise is a nonsteady process. Rate of sea-level rise has been observed to accelerate since the past two decades ${ }^{47}$; therefore, these results have significant implications for the community of science researchers that examine sea-level rise past and present, and for how society prepares for coastal flooding and inundation hazards in the coming decades to centuries.

\section{Methods}

Radiocarbon date calibration. Calib Rev 7.0.4 was used to calibrate the radiocarbon ages collected in $1970 \mathrm{~s}^{17,19,21}$. Calibration data set marina13.14c is used with Delta $R=-30 \pm 9$. The new calibrated calendar year ages are 11,901.5 \pm 335.5 calendar years BP for the top of Dream Bank and 22,361 \pm 428 calendar years BP for the base of Southern Bank. These ages are not incorporated into the age model but are used to only indicate that these reefs grew during last deglaciation.

Data collection R/V Falkor. During a 15-day long research cruise in September 2012 onboard R/V Falkor, funded by the Schmidt Ocean Institute, high-resolution multibeam sonar and $3.5 \mathrm{kHz}$ seismic data sets were acquired over 10 drowned 
coralgal reefs on the south Texas shelf edge. The research vessel was equipped with state-of-the-art instrumentation, including a Kongsberg EM 710 multibeam echo sounder to collect high-resolution $(<0.5 \mathrm{~m})$ bathymetric maps and a highresolution seabed mapping ( $3.5 \mathrm{kHz}$ seismic) system, Knudsen CHIRP 3260, to image the sub sea-floor sedimentary units. The ancillary components of the multibeam system included: SeaPath 320 heading, attitude, and positioning sensor, CNAV positioning correction service, and Valeport SV profiler. Multibeam data was processed using Caris 7.1 and further imported to Arc G.I.S. 10.1 to build and investigate the bathymetric maps of these drowned reefs. The CHIRP data was analyzed utilizing the Echo Post Survey software.

Hypsometric curves-data analysis. Hypsometric curves are generated for nine of the ten drowned coralgal reefs (Fig. 5a). Bathymetry data sets are clipped into subdata sets encompassing each individual drowned reef. The total surface area of each reef is divided into $1 \mathrm{~m}$-depth intervals and the surface area of each interval is calculated by the number of pixels (each one representing one square meter). To create a hypsometric curve for each individual reef, the percentage of each one meter depth interval is determined using their calculated surface area. Each peak in a given reef's hypsometric curve represents individual terrace. When the nine hypsometric curves are plotted together, overlapping peaks identify common terrace depth zones. For each common terrace depth zone, a median terrace depth is determined. Depth uncertainties are evaluated as the difference between the median terrace depth values and their maximum or minimum depth range.

Computing paleo terrace depth. In the absence of chronologic dates, the current depths of the terrace zones, ice-volume sea-level curve ${ }^{15}$, in addition to GIA ${ }^{39}$ and subsidence ${ }^{40}$ rates, are used to estimate paleo terrace depths. First, the terrace depth zones (with depth uncertainties) are compared with an ice-volume sea-level curve ${ }^{15}$ to identify the age range (including uncertainties) for the development of each terrace zone. To estimate the paleo terrace depth, depth change for each terrace due to GIA and subsidence is calculated by multiplying the estimated age range of each terrace depth zone with avg. rate of GIA ${ }^{39}(0.71 \mathrm{~mm}$ per year $)$ and subsidence ${ }^{40}$ $(0.5 \mathrm{~mm}$ per year). The total change in depth is calculated by adding GIA and subsidence (uplift is considered positive and subsidence is considered negative). The estimated total depth change is added to the current terrace depth to identify the paleo terrace depth for each terrace. The paleo terrace depths are further compared with an ice-volume sea-level curve ${ }^{15}$ to estimate the age range for the development of each paleo terrace.

Two assumptions are included in the analyses: the rates of subsidence ${ }^{40}$ $\left(0.5 \mathrm{~mm}\right.$ per year) and $\mathrm{GIA}^{39}(0.71 \mathrm{~mm}$ per year) are considered linear and $95 \%$ probability ice-volume sea-level curve ${ }^{15}$ is used.

Data source. Digital data generated by the environmental sensor systems onboard R/V Falkor, including multibeam, are archived and freely available to the public via Rolling Deck to Repository and given Digital Object Identifiers-http://www. rvdata.us/catalog/FK005B

Data availability. All relevant data are available from authors.

Received: 24 November 2016 Accepted: 9 August 2017

Published online: 19 October 2017

\section{References}

1. Fairbanks, R. G. A 17,000-year glacioeustatic sea-level record: influence of glacial melting rates on Younger Dryas event and deep-ocean circulation. Nature 342, 637-642 (1989).

2. Bard, E., Hamelin, B., Fairbanks, R. G. \& Zindler, A. Calibration of the $14 \mathrm{C}$ timescale over the past 30,000 years using mass spectrometric U-Th ages from Barbados corals. Nature 345, 405-410 (1990a).

3. Bard, E. et al. Deglacial sea-level record from Tahiti corals and the timing of global meltwater discharge. Nature 382, 241-244 (1996).

4. Alley, R. B. et al. Holocene climatic instability: a prominent, widespread event 8200 yr ago. Geology 25, 483-486 (1997).

5. Yokohama, Y. et al. Timing of the last glacial maximum from observed sea-level minima. Nature 406, 713-716 (2000).

6. Hanebuth, T., Stattegger, K. \& Grootes, P. M. Rapid flooding of the sunda shelf: a late-glacial sea-level record. Science 288, 1033-1035 (2000).

7. Lambeck, K., Anzidei, M., Antonioli, F., Benini, A. \& Esposito, A. Sea-level in Roman time in the central Mediterranean and implications for recent change. Earth Planet. Sci. Lett. 224, 563-575 (2004).

8. Alley, R. B., Clark, P. U., Huybrechts, P. \& Joughin, I. Ice-sheet and sea-level changes. Science 310, 456-460 (2005).
9. Bird, M. I. et al. An inflection in the rate of early mid-holocene eustatic sea-level rise: a new sea-level curve from Singapore. Estuar. Coast. Shelf Sci. 71, 523-536 (2007).

10. De Deckker, P. \& Yokoyama, Y. Micropalaeontological evidence for late quaternary sea-level changes in Bonaparte Gulf, Australia. Glob. Planet. Change 66, 85-92 (2009).

11. Bird, M. I. et al. Punctuated eustatic sea-level rise in the early mid-Holocene. Geology 38, 803-806 (2010).

12. Bard, E., Hamelin, B. \& Delanghe-Sabatier, D. Deglacial meltwater pulse 1B and Younger Dryas sea-levels revisited with boreholes at Tahiti. Science 327, 1235-1237 (2010).

13. Deschamps, P. et al. Ice-sheet collapse and sea-level rise at the Bølling warming 14,600 years ago. Nature 483, 559-564 (2012).

14. Camoin, G. F. et al. Reef response to sea-level and environmental changes during the last deglaciation: Integrated ocean drilling program expedition 310, tahiti sea-level. Geology 40, 643-646 (2012).

15. Lambeck, K., Rouby, H., Purcell, A. \& Sun, Y. Sambridge sea-level and global ice volumes from the Last Glacial Maximum to the Holocene. Proc. Natl Acad. Sci. USA 111, 15296-15303 (2014).

16. Trowbridge, A. C. Building of the Mississippi delta. Am. Assoc. Pet. Geol. 14, 867-901 (1930).

17. Rezak, R. \& Bright, T. J. Coral reefs and banks of Texas outer continental shelf. AAPG Bull. 60, 713-714 (1976).

18. Bright, T. J. and Rezak, R. A Biological and Geological Reconnaissance of Selected Topographical Features on the Texas Continental Shelf. A report to Bureau of Land Management (Texas A\&M University, College Station, 1976).

19. Belopolsky, A. V. \& Droxler, A. W. Uppermost Pleistocene transgressive coralgal reefs on the edge of the South Texas shelf: analogs for reefal reservoirs buried in siliciclastic shelf. Advanced Reservoir Characterization for the 21st Century (ed. Hentz T. F.) 41-50 (Gulf Coast Sect. SEPM, Houston, 1999).

20. Weight, R. W. R., Anderson, J. B. \& Fernandez, R. A. Rapid mud accumulation on the central Texas shelf linked to climate change and sea-level rise. J. Sediment. Res. 81, 743-761 (2011).

21. Droxler, A. W. \& Jorry, S. J. Deglacial origin of barrier reefs along low-latitude mixed siliclastic and carbonate continental shelf edges. Annu. Rev. Mar. Sci. 5 , 23.1-23.36 (2013).

22. Gladfelter, E. H., Monahan, R. K. \& Gladfelter, W. B. Growth rates of five reefbuilding corals in the Northeastern Caribbean. Bull. Mar. Sci. 28, 728-734 (1978).

23. Zimmer, B., Precht, W., Hickerson, E. \& Sinclair, J. Discovery of Acropora palmata at the Flower Garden Banks national marine sanctuary, northwestern Gulf of Mexico. Coral Reefs 25, 192 (2006).

24. Precht, W. et al. Back to the future: the history of acroporid corals at the Flower Garden Banks, Gulf of Mexico, USA. Mar. Geol. 349, 152-161 (2014).

25. Rezak, R., Bright, T. J. \& McGrail, D. W. Reefs and Banks of the Northwestern Gulf of Mexico: Their Geological, Biological, and Physical Dynamics. (Texas A\&M Research Foundation, College Station, TX, 1983).

26. Schlager, W. Carbonate Sedimentology And Sequence Stratigraphy. SEPM Concepts in Sedimentology and Paleontology (SEPM, Tulsa, 2005).

27. Chappell, J. \& Polach, H. Post-glacial sea-level rise from a coral record at Huon Peninsula, Papua New Guinea. Nature 349, 147-149 (1991).

28. Blanchon, P. \& Shaw, J. Reef drowning during last deglaciation: evidence for catastrophic sea-level rise and ice-sheet collapse. Geology 23, 4-8 (1995).

29. Clark, P. U. et al. Freshwater forcing of abrupt climate change during the last glaciation. Science 293, 283-287 (2001).

30. Peltier, W. R. \& Fairbanks, R. G. Global glacial ice volume and last glacial maximum duration from an extended Barbados sea-level record. Quat. Sci. Rev. 25, 3322-3337 (2006).

31. Neumann, A. C. \& Macintyre, I. Reef response to sea level rise: keep-up, catchup or give-up. Proc. of the Fifth International Coral Reef Congress Vol. 3, 105-110 (Morea, French Polynesia, Antenne Museum-Ephe, 1985).

32. Nash, H., Furiness, S. J. \& Tunnell, W. T. Jr. What is known about species richness and distribution on the outer-shelf south Texas Banks? Gulf Caribb. Res. 25, 9-18 (2013).

33. Gischler, E. Indo-Pacific and Atlantic spurs and grooves revisited: the possible effects of different Holocene sea-level history, exposure, and reef accretion rate in the shallow fore reef. Facies 56, 173-177 (2010).

34. Duce, S. et al. A morphometric assessment and classification of coral reef spur and groove morphology. Geomorphology 265, 68-83 (2016).

35. Lindquist, P. Geology of the South Texas Shelf Banks. (MS thesis, Texas A\&M University, 1978)

36. Locker, S. D., Hine, A. C., Tedesco, L. P. \& Shinn, E. A. Magnitude and timing of episodic sea-level rise during the last deglaciation. Geology 24, 827-830 (1996). 
37. Carter, R. M., Carter, L. \& Johnson, D. P. Submergent shorelines in the SW pacific: evidence for an episodic post-glacial transgression. Sedimentology 33, 629-649 (1986).

38. Flower, B. P., Hastings, D. W., Hill, W. H. \& Quinn, T. M. Phasing of deglacial warming and Laurentide ice sheet meltwater in the Gulf of Mexico. Geology 32, 597-600 (2004).

39. Milne, G. A. \& Mitrovica, J. Searching for eustasy in deglacial sea-level histories. Quat. Sci. Rev. 27, 2292-2302 (2008).

40. Winker, C. D. Late Pleistocene Fluvial-Deltaic Deposition: Texas Coastal Plain And Shelf. 187 (MA thesis, The University of Texas at Austin, 1979).

41. North Greenland Ice Core Project members North Greenland Ice Core Project oxygen isotope data. IGBP PAGES/World Data Center for Paleoclimatology Data Contribution Series \# 2004-059 (NOAA/NGDC Paleoclimatology Program, Boulder CO, USA, 2004).

42. Steffensen, J. P. et al. High-resolution Greenland ice core data show abrupt climate change happens in few years. Science 321, 681-684 (2008).

43. Lidz, B. H. \& Shinn, E. A. Paleoshorelines, reefs, and a rising sea: South Florida, USA. J. Coast. Res. 7, 203-229 (1991).

44. Törnqvist, T. E. \& Hijma, M. P. Links between early Holocene ice-sheet decay, sea-level rise and abrupt climate change. Nat. Geosci. 5, 601-606 (2012).

45. Bamber, J. L. \& Aspinall, W. P. An expert judgement assessment of future sea-level rise from the ice sheets. Nat. Clim. Change 3, 424-427 (2013).

46. DeConto, R. M. m. \& Pollard, D. Contribution of Antarctica to past and future sea-level rise. Nature 531, 591-597 (2016).

47. Chen, $\mathrm{X}$. et al. The increasing rate of global mean sea-level rise during 1993-2014. Nat. Clim. Change 7, 492-495 (2017).

\section{Acknowledgements}

The data collected in this study are based upon work supported by the Schmidt Ocean Institute during cruise FK005B aboard R/V Falkor. We thank the Schmidt Ocean

Institute and the R/V Falkor officers, crew members, and onboard technicians. We are grateful to Jean Aroom at the Rice University G.I.S. Datacenter for training the senior author with advanced Arc G.I.S. applications..

\section{Author contributions}

P.K., A.W.D., J.W.T. and T.C.S. participated on the R/V Falkor; P.K. and J.A.N. processed the data; P.K., A.W.D. and J.A.N. co-wrote the manuscript; P.K.,

A.W.D., J.A.N., J.W.T. and T.C.S. edited the manuscript.

\section{Additional information}

Supplementary Information accompanies this paper at doi:10.1038/s41467-017-00966-X.

Competing interests: The authors declare no competing financial interests.

Reprints and permission information is available online at http://npg.nature.com/ reprintsandpermissions/

Publisher's note: Springer Nature remains neutral with regard to jurisdictional claims in published maps and institutional affiliations.

\begin{abstract}
(c) (i)
Open Access This article is licensed under a Creative Commons Attribution 4.0 International License, which permits use, sharing, adaptation, distribution and reproduction in any medium or format, as long as you give appropriate credit to the original author(s) and the source, provide a link to the Creative Commons license, and indicate if changes were made. The images or other third party material in this article are included in the article's Creative Commons license, unless indicated otherwise in a credit line to the material. If material is not included in the article's Creative Commons license and your intended use is not permitted by statutory regulation or exceeds the permitted use, you will need to obtain permission directly from the copyright holder. To view a copy of this license, visit http://creativecommons.org/ licenses/by/4.0/.
\end{abstract}

(C) The Author(s) 2017 